\title{
Nutritional requirements of fish
}

\author{
BY COLIN B. COWEY AND C. YOUNG CHO \\ Department of Nutritional Sciences, University of Guelph, Guelph, Ontario N1G 2W1 and \\ Fisheries Research Section, Ministry of Natural Resources, Ontario, Canada L6A 1S9
}

The impetus for accurate information on the nutrient requirements of fish derives very largely from the development, in many parts of the world, of an aquaculture industry that is dependent on artificial feeds. At the same time such information can provide the basis for comparative nutrition, whereby features of the nutrition of cold-blooded, water-breathing and mainly, carnivorous vertebrates which differ from the pattern largely common to omnivorous mammals are identified. Since this topic was last addressed (Cowey, 1988) the aquaculture industry has continued to grow, fuelled both by the continuing overexploitation of the marine environment, resulting in declining yields, and by the high quality of aquaculture products.

The first serious studies on nutritional requirements of fish were made in the $1950 \mathrm{~s}$. Since then much has been learned concerning fish husbandry, water quality, pellet quality (water stability) of fish diets and so on. Consequently, general methodological standards in nutritional experiments have improved greatly and some of the early values for nutrient requirements need to be revised, usually downward.

\section{VITAMINS}

Many of the earlier measurements, particularly of the vitamin B requirements of salmonids, indicated requirement levels much higher than those of mammals and birds. More recent studies on rainbow trout (Oncorhynchus mykiss) have demonstrated much lower requirements in line with those of omnivorous mammals.

In Table 1 the requirements of rainbow trout for certain B vitamins, obtained in recent experiments on rapidly growing young fish given a semi-purified, steam-pelleted diet are

Table 1. Some vitamin B requirements ( $\mathrm{mg} / \mathrm{kg}$ air-dry diet) for maximal weight gain of young rainbow trout (Oncorhynchus mykiss) in comparison with (US) National Research Council (1981) recommended levels and with those of chick and piglet

\begin{tabular}{lcccc}
\hline \hline & Trout* & $\begin{array}{c}\text { National Research } \\
\text { Council (1981) }\end{array}$ & Chick $\dagger$ & Piglet $\ddagger$ \\
\hline Riboflavin & $3 \cdot 6$ & 20 & $3 \cdot 6$ & $3 \cdot 0$ \\
Pyridoxine & $2 \cdot 0$ & 10 & $3 \cdot 0$ & $1 \cdot 5$ \\
Biotin & $0 \cdot 1$ & 10 & $0 \cdot 15$ & $0 \cdot 1$ \\
Pantothenic acid & $12 \cdot 1$ & 40 & $10 \cdot 0$ & $13 \cdot 0$ \\
Thiamin & $1 \cdot 0$ & 10 & $1 \cdot 8$ & $1 \cdot 3$ \\
Vitamin $B_{12}$ & $0 \cdot 007$ & 0.02 & 0.009 & $0 \cdot 02$ \\
Folic acid & 0.56 & $5 \cdot 0$ & 0.55 & 0.30 \\
\hline
\end{tabular}

* Woodward (1989).

$\dagger$ National Research Council (1984).

$\ddagger$ National Research Council (1988). 
compared with the recommended levels of cold-water fishes based on earlier estimates from experiments on salmonids (National Research Council, 1981). The more recent measurements are several-fold lower (in some cases an order of magnitude lower) than the earlier measurements. Moreover, there is, as would be expected on metabolic grounds, close agreement between the requirements of cold-blooded carnivorous fish and omnivorous mammals.

Another matter of interest is the vitamin $E$ requirement of fish. As a lipid-soluble antioxidant the vitamin $E$ requirement is related to the intake of polyunsaturated fatty acids. From experiments carried out at a water temperature of $15^{\circ}$, Cowey et al. (1981) demonstrated a vitamin $E$ requirement of $30 \mathrm{mg} / \mathrm{kg}$ diet (containing $10 \mathrm{~g}$ linolenic acid $/ \mathrm{kg}$ ) for rainbow trout; with $100 \mathrm{~g}$ fish oil $/ \mathrm{kg}$ diet the requirement was $50 \mathrm{mg} / \mathrm{kg}$ diet (Cowey et al. 1983). The high-energy diets currently used in salmonid cultivation, with up to $300 \mathrm{~g}$ fish oil $/ \mathrm{kg}$, probably necessitate greater supplementation with vitamin $\mathrm{E}$, possibly of the order of $100 \mathrm{mg} / \mathrm{kg}$. A complicating factor is that water temperatures may fall to very low levels, $5^{\circ}$ or lower, and there are indications that vitamin $E$ requirement may increase as water temperature decreases (Cowey et al. 1984). The critical experiments remain to be done.

Nutritional interactions between vitamins $\mathrm{A}$ and $\mathrm{E}$ may also occur. Frigg \& Broz (1984) observed that $\alpha$-tocopherol levels in chick plasma were markedly decreased by high levels of dietary vitamin A supplementation ( $15 v .3 \mathrm{mg}$ retinol equivalent $/ \mathrm{kg}$ ). The interaction has not yet been examined in fish, but with very high levels of fish oil currently being added to salmon (Salmo salar) diets, very high concentrations of vitamin A might occur more or less adventitiously.

\section{MINERALS}

Mineral nutrition is complicated because fish are able to obtain appreciable quantities of essential cations from the environmental water. This is especially true of marine fish. Sakamoto \& Yone (1979) showed that a purified diet for red sea bream (Chrysophrys major) containing only ferric citrate and $\mathrm{Na}_{3} \mathrm{PO}_{4}$ as a mineral supplement was as effective in maintaining growth and freedom from pathology as a similar diet containing a complete mineral supplement. Consequently, a stated cation requirement for freshwater fish should specify the concentration of that cation in the water in which the measurement was made. While the role of the environment as a source of cations applies to most metals, it has been most closely studied for $\mathrm{Ca}$ and this will be used by way of illustration of the role of the environment as a source of cations; it may be noted that a quantitative dietary $\mathrm{Ca}$ requirement has not been demonstrated in salmonids. In other species a requirement has been demonstrated only under somewhat unusual conditions, i.e. the use of water, free of $\mathrm{Ca}$ (Wilson, 1991).

About $95 \%$ of fish body $\mathrm{Ca}$ is contained in the acellular bone (bone without enclosed osteocytes) and scales but these tissues seem to play only a minor role in Ca dynamics. Thus, the skeleton does not serve as a reservoir of $\mathrm{Ca}$ as in mammals; the environmental water might be seen as fulfilling this role. During periods of dietary $\mathrm{Ca}$ deprivation fish may rely entirely on the environment for $\mathrm{Ca}$.

$\mathrm{Ca}$ concentrations are generally less homeostatic in plasma and tissues of fish than in those of other vertebrates. In freshwater fish, at least, the gills may be regarded as the main Ca-regulating organ because of the facility with which they transport $\mathrm{Ca}$ from 
environmental water directly to the blood. Ca can be transported from environmental concentrations as low as $0.015 \mathrm{~mm}$ into blood where normal Ca concentrations are 2-3 $\mathrm{mm}$ (Fontaine et al. 1972). Ca transport across the gills is thought to involve apical cAMP-regulated channels and active extrusion across the basolateral membrane (Fenwick, 1989). A Ca-activated ATPase (EC 3.6.1.38) in these cells increases in activity in response to transfer to water low in Ca (Flik \& Perry, 1989) and activity decreases during acclimation to seawater.

While a dietary requirement for cholecalciferol has been demonstrated in rainbow trout, fish deficient in vitamin $\mathrm{D}$ showed no change in Ca concentration in plasma and other tissues (Barnett et al. 1982a). In addition, inclusion of cholecalciferol or 25hydroxycholecalciferol or 1,25-dihydroxycholecalciferol in rainbow trout diets did not lead to detectable levels of 25-hydroxycholecalciferol in the plasma of the fish (Barnett et al. 1982 b). Hormonal interactions involved in $\mathrm{Ca}$ homeostasis in fish remain to be clarified. Fish have no parathyroid glands and so lack parathormone. The function of calcitonin (formed in the ultimobranchial glands) has not been established; injection of calcitonin has had inconsistent effects on plasma $\mathrm{Ca}$ concentration. The principal hormone involved in lowering plasma $\mathrm{Ca}$ appears to be stanniocalcin from the corpuscles of Stannius (located at the posterior end of the kidney). In many species of fish prolactin is a hypercalcaemic hormone, but it has not yet been shown to be effective in inducing hypercalcaemia in freshwater trout.

\section{CARBOHYDRATES}

The capacity of most fish to assimilate and metabolize dietary carbohydrate is limited (Cowey, 1988). Given this caveat, warm-water fish in general appear better able to use dietary carbohydrate than do cold-water and marine fish. As noted earlier (Cowey, 1988) gelatinization of starch leads to its more efficient use. There is some species variation in utilization of mono- and disaccharides. Fructose, galactose and lactose are not well used by any species and in channel catfish (Ictalurus punctatus) this also holds true for maltose and glucose (Wilson \& Poe, 1987). By contrast, these latter sugars, when included (272 $\mathrm{g} / \mathrm{kg}$ ) in diets for white sturgeon (Acipenser transmontanus), gave better growth rates than did starch or dextrin used at the same dietary concentration (Hung et al. 1989). They were also lipogenic; sturgeon given diets containing glucose or maltose were hyperlipidaemic, and the activities of glucose-6-phosphate dehydrogenase ( $E C$ 1.1.1.49), malic enzyme $(E C 1.1 .1 .38,1.1 .1 .40)$ and isocitrate dehydrogenase $(E C 1.1 .1 .41)$ in their livers were significantly enhanced.

Blood glucose concentration is not closely controlled in fish despite the fact that plasma insulin levels are comparable with those of omnivorous mammals (Hilton et al. 1987). Fish may be said, therefore, to resemble mammals with non-insulin-dependent diabetes. Several recent studies examined the binding of insulin to receptors in skeletal muscle. That of Gutierrez et al. (1991) showed trout muscles to have 10-30-fold fewer insulin receptors per $\mu \mathrm{g}$ protein than the red and white skeletal muscle of the rat. Over all, insulin-receptor binding in trout is lower than that reported for mammals. From experiments with diets of different carbohydrate content (70 or $140 \mathrm{~g}$ dextrin $/ \mathrm{kg}$ ) Gutierrez et al. (1991) concluded that the higher glycaemic levels observed in the trout given the high-carbohydrate diet were not a consequence of impaired binding of insulin to its receptors in skeletal muscles. Assays on trout livers from this experiment showed 
specific binding of insulin to be lower in the fish given the high-carbohydrate diet. It appears that the phenomenon of down regulation of receptor numbers by circulating levels of insulin may, under some so far unspecified circumstances, be applicable to fish liver.

A sluggish and uneven response to dietary carbohydrate was seen in recent experiments by Mazur et al. (1992). A suggested explanation was that the pancreatic D-cells, producing somatostatins, are sensitive to glucose, and as piscine somatostatin inhibits insulin release (Sheridan et al. 1987) it may limit insulin levels in the plasma when carbohydrate is administered. This conflicts directly with the findings of Hilton et al. (1987), that a diet containing highly digestible carbohydrate given to rainbow trout gave rise to high levels of plasma insulin $3 \mathrm{~h}$ after feeding. No resolution of these findings has yet been forthcoming.

\section{LIPIDS}

Diets for cold-water fish usually contain $150-250 \mathrm{~g}$ fish oil $/ \mathrm{kg}$, although the amounts needed to meet essential fatty acid (EFA) requirements are very small (Cowey, 1988). Diets for warm-water fish usually contain $50-100 \mathrm{~g} \mathrm{lipid} / \mathrm{kg}$.

The experiments of Castell et al. (1972) demonstrated that rainbow trout have appreciable capacity to metabolically modify dietary fatty acids. Dietary $18: 1(n-9)$, $18: 2(n-6)$ and $18: 3(n-3)$ gave rise respectively to $20: 3(n-9), 20: 4(n-6)$ and to $22: 6(n-3)$ in the liver and other tissues. The pathways operating in these desaturation and elongation reactions have not been demonstrated in rainbow trout and other fish, but were assumed to occur by a series of reactions similar to those occurring in omnivorous mammals. Thus, docosahexaenoic acid would be formed from linolenic acid by the sequential actions of $\triangle 6-, \triangle 5$-, and $\triangle 4$-desaturases, docosahexaenoate, 22:6(n-3) being formed from $22: 5(n-3)$ by the action of a $\triangle 4$-desaturase. Recent work in mammals (Voss et al. 1991) has shown that $22: 6(n-3)$ is indeed formed from $22: 5(n-3)$, but by a pathway independent of a $\triangle 4$-desaturase. The results of Voss et al. (1991) indicate that rat liver microsomes do not possess $\triangle 4$-desaturase activity. The pathway from $22: 5(n-3)$ to $22: 6(n-3)$ in rat hepatocytes involves microsomal chain elongation of $22: 5(n-3)$ to $24: 5(n-3)$ followed by its desaturation to $24: 6(n-3)$; this microsomal product is then metabolized, via $\beta$-oxidation, to $22: 6(n-3)$.

None of the desaturases present in fish liver microsomes have been purified and characterized. However, if an analogy is drawn between pathways of fatty acid desaturation and elongation in mammals and those in fish, it seems highly unlikely that $\triangle 4$-desaturase activity is present in liver microsomes of trout or of other fish.

Although a dietary supply of linolenic acid is said to meet the EFA requirements of rainbow trout, it continues to be the case that a small, but significant requirement for linoleic acid, or in the case of marine fish, of 20:4(n-6) cannot be ruled out (Cowey, 1988). In compositional studies on cultured cells from rainbow trout, Tocher (1990), emphasized that the high level of $20: 4(n-6)$ in phosphatidyl inositol is indicative of the presence of 'precise and tightly controlled' mechanisms for the maintenance of $20: 4(n-6)$ in fish cells where it would be required to fulfil a role in eicosanoid synthesis. Similar findings were made in studies by Tocher \& Mackinlay (1990) on cultured cells of turbot (Scophthalmus maximus). As yet the critical growth experiments, needed to establish a dietary (n-6) requirement in fish, remain to be carried out. 


\section{ENERGY REQUIREMENT}

Food intake tends to be controlled by the energy need of the animal and, accordingly, energy requirement will regulate within certain limits the intake of nutrients. Therefore, it is important that the energy content of the diet be adjusted so as to promote the desired intake of all nutrients.

A feature of energy requirement in poikilotherms is that it is affected by environmental temperature. This controls metabolic rate and in addition the maintenance energy requirement of cold-water fish is especially influenced by a rise in water temperature from low levels up to and above their (generalized) optimum. Thus, the maintenance requirement of sockeye salmon (Oncorhynchus nerka) at $20^{\circ}$ is seven times its value at $1^{\circ}$ (Brett et al. 1969). Maintenance energy requirement is approximated by fasting heat production $(\mathrm{kJ} / \mathrm{d})$ which is given by:

$$
\left(-1.04+3 \cdot 26 \mathrm{~T}-0.05 \mathrm{~T}^{2}\right) \mathrm{W}^{0.824} \text {, }
$$

where $\mathrm{T}$ is temperature $\left(^{\circ}\right)$, and $\mathrm{W}$ is weight $(\mathrm{kg})(\mathrm{Cho}, 1992)$. Fasting heat production generally accounts for about $30 \%$ of digestible energy (DE) intake depending on temperature. Of the remaining energy, approximately $20 \%$ is lost in the form of heat increment of feeding and non-faecal losses.

The dietary energy required for the production of $1 \mathrm{~kg}$ biomass of salmonids is, in the case of rapidly growing fingerlings, approximately $12 \mathrm{MJ} D E$. For larger fish (1-2 kg live weight) requirements are higher, about $20 \mathrm{MJ} \mathrm{DE}$ being needed. In line with this, diets presently used in salmonid production have energy densities in the range 17-22 MJ $\mathrm{DE} / \mathrm{kg}$. The protein in the fingerling diets amounts to $25 \mathrm{~g}$ digestible protein (DP)/MJ $\mathrm{DE}$ and in diets for larger fish $20 \mathrm{~g} \mathrm{DP} / \mathrm{MJ} \mathrm{DE}$. Energy retention in salmonid fish is of the order of $45-55 \%$ DE, appreciably greater than is the case in mammals.

\section{PROTEINS AND AMINO ACIDS}

Amino acid requirements. In most of the test diets used to measure amino acid requirements, the $\mathrm{N}$ component has consisted of both a crystalline amino acid mixture (making up about $50 \%$ of the $\mathrm{N}$ component) and some whole protein. Such diets gave growth rates that were inferior, often markedly so, to diets of similar amino acid composition in which the $\mathrm{N}$ component was entirely protein (Cowey, 1988). Recently Kim et al. $(1992 a, b)$ obtained high growth rates with rainbow trout given diets containing up to $270 \mathrm{~g}$ crystalline amino acid mixture $/ \mathrm{kg}$ plus $90 \mathrm{~g}$ protein $/ \mathrm{kg}$ as the $\mathrm{N}$ component. No special measures were taken to prevent rapid absorption of crystalline amino acids in the gastrointestinal tract, which might lead to elevated concentrations of amino acids in tissues and enhanced catabolism of those amino acids; it is not obvious why similar diets failed to provide such high rates of growth in other laboratories.

In these experiments Kim et al. (1992a) demonstrated a total S amino acid requirement of $8 \mathrm{~g} / \mathrm{kg}$ diet $(23 \mathrm{~g} / \mathrm{kg}$ dietary protein); they also showed that D-methionine is used as efficiently as L-methionine for weight gain and that, on a molar $\mathrm{S}$ basis, cysteine will replace $42 \%$ of the methionine requirement. The lysine and arginine requirements reported by Kim et al. (1992b) were 13 and $14.1 \mathrm{~g} / \mathrm{kg}$ diet $(37.1$ and $40.3 \mathrm{~g} / \mathrm{kg}$ dietary protein) respectively. Kim et al. (1992b) also demonstrated that there are no interactions between dietary arginine and lysine levels. These values are in line with other recent measurements (total S amino acid requirement of $9.6 \mathrm{~g} / \mathrm{kg}$ diet or $24 \mathrm{~g} / \mathrm{kg}$ dietary protein 
Cowey et al. (1992), arginine requirement $14 \mathrm{~g} / \mathrm{kg}$ diet or $42 \mathrm{~g} / \mathrm{kg}$ dietary protein (Cho et al. 1992)). These requirement values, for all three amino acids are very much at the low end of previously reported requirements for rainbow trout.

Non-essential amino acids as a preferred energy source. In another recent study Kim et al. (1991) re-examined the requirement of fingerling rainbow trout for dietary protein. They obtained a value, to achieve maximal growth, of not more than $300 \mathrm{~g}$ protein $/ \mathrm{kg}$ diet (the reference protein being casein, a highly digestible protein, supplemented with methionine and arginine in a diet containing $100 \mathrm{~g}$ lipid $/ \mathrm{kg}$ ), a value lower than currently accepted values (National Research Council, 1981). It was also shown that some of this dietary protein could be replaced with alanine or a non-essential amino acid mixture, but could not be replaced with dextrin on an equal DE basis. The requirement of the trout for essential amino acids was met by a diet containing $240 \mathrm{~g}$ casein (supplemented with arginine and methionine) $/ \mathrm{kg}$, the remaining $60 \mathrm{~g} / \mathrm{kg}$ of supplemented casein was seen as meeting energy needs. Kim et al. (1991) regard a diet containing $250 \mathrm{~g}$ whole protein $/ \mathrm{kg}$ together with $100 \mathrm{~g}$ non-essential amino acids/kg (Table 2 of Kim et al. (1991)) as having only 250 g crude protein $(\mathrm{N} \times 6 \cdot 25) / \mathrm{kg}$. They conclude 'protein requirement of rainbow trout is not more than $25 \%$ when appropriate energy sources that have metabolizable energy (ME) values equivalent to protein are used to substitute for protein'. It is a peculiar concept that alanine, or a non-essential amino acid mixture, when included in a diet, should not be regarded as part of the crude protein content.

We have worked along similar lines to Kim and his colleagues (Kim et al. 1991, $1992 a, b)$, supplying in the diet a concentration of whole protein that would just meet the essential amino acid requirements of the fish and attempting to achieve maximal growth rates by supplementing this diet with different non-essential or essential amino acids or mixtures of amino acids. Diet 1 (Table 2) which meets the essential amino acid requirements of rainbow trout contained $251 \mathrm{~g}$ protein $/ \mathrm{kg}$ and had a DE content of 15 $\mathrm{MJ} / \mathrm{kg}$, an appreciable part of which was supplied by lipid $(161 \mathrm{~g} / \mathrm{kg})$. Energy densities of diets 1-6 were $15-16 \mathrm{MJ} / \mathrm{kg}$, diet 7 contained $18 \mathrm{MJ} / \mathrm{kg}$. As a proportion of DE, DP levels ranged from $16.7 \mathrm{~g} / \mathrm{MJ}$ (diet 1 ) to about $22 \mathrm{~g} / \mathrm{MJ}$ (diets $2-7$ ). It can be seen from Table 3 that supplementation of the basal diet with either alanine, a mixture of glycine and glutamine, or a complete mixture of non-essential amino acids did not enhance growth rate over that obtained with the basal diet. By contrast substitution with an essential amino acid mixture (diet 5) led to a significant increase in growth rate to a value comparable with that of a high fishmeal diet (diet 6); further increase in growth rate occurred when nutrient density was again increased (diet 7). The second experiment (Tables 2 and 4 ) was carried out mainly to determine whether any essential amino acids might possibly be limiting in the diets supplying only $251 \mathrm{~g} \mathrm{DP} / \mathrm{kg}$ or $251 \mathrm{~g}$ DP together with one or more non-essential amino acids (i.e. diets $1-4$, Expt 1 ). To this end diet 1 (Expt 2) served as a control diet with an energy density equal to that of the other diets, diet 2 was the control diet together with a non-essential amino acid mixture, diet 3 was the control diet with alanine (shown by Kim et al. (1991) to substitute for protein on an equal ME basis), the remaining diets had added to them essential amino acids that might possibly be limiting. However, these essential amino acids were sensibly without effect on growth rate (diets $3-7$ ) and only when a complete essential amino acid mixture was added to the diet was growth rate enhanced (diet 8). Even so, it was inferior to that of a high-fishmeal diet (diet 9). 
Table 2. Compositions of diets used to examine the effect on growth of rainbow trout (Oncorhynchus mykiss) of supplementation with non-essential amino acids (NEAA) of a basal diet formulated to meet their essential amino acid $(E A A)$ requirements at a minimal concentration of dietary protein $(\mathrm{g} / \mathrm{kg} \text { feed })^{*}$

\begin{tabular}{|c|c|c|c|c|c|c|c|c|c|}
\hline Diet no. & 1 & 2 & 3 & 4 & 5 & 6 & 7 & 8 & 9 \\
\hline \multicolumn{10}{|l|}{ Expt 1: } \\
\hline Basal mix $\dagger$ & 615 & 615 & 615 & 615 & 615 & 615 & 870 & & \\
\hline Ala & - & 102 & 43 & - & - & - & - & & \\
\hline Gly + Gln & - & - & 42 & - & - & - & - & & \\
\hline NEAA $\ddagger$ & - & - & - & 124 & - & - & - & & \\
\hline EAA $\S$ & - & - & - & - & 124 & - & - & & \\
\hline Fishmeal & - & - & - & - & - & 137 & - & & \\
\hline Starch, maize & 245 & 188 & 205 & 166 & 166 & 168 & - & & \\
\hline Fish oil & 140 & 95 & 95 & 95 & 95 & 80 & 130 & & \\
\hline \multicolumn{10}{|l|}{ Digestible protein } \\
\hline Digestible fat $(\mathrm{g} / \mathrm{kg})$ & 161 & 116 & 116 & $\begin{array}{l}349 \\
116\end{array}$ & 116 & 115 & 168 & & \\
\hline \multicolumn{10}{|l|}{ Digestible energy } \\
\hline$(\mathrm{MJ} / \mathrm{kg})$ & 15 & 16 & 15 & 16 & 16 & 15 & 18 & & \\
\hline \multicolumn{10}{|l|}{ Expt 2: } \\
\hline Basal mix $\dagger$ & 615 & 615 & 615 & 615 & 615 & 615 & 615 & 615 & 615 \\
\hline Ala & - & - & 115.5 & - & - & - & - & - & - \\
\hline Met & - & - & $8 \cdot 5$ & $8 \cdot 5$ & $8 \cdot 5$ & $8 \cdot 5$ & $8 \cdot 5$ & - & - \\
\hline Arg & - & - & - & - & $14 \cdot 6$ & $14 \cdot 6$ & $14 \cdot 6$ & - & - \\
\hline Lys & - & - & - & - & - & $12 \cdot 4$ & $12 \cdot 4$ & - & - \\
\hline $\operatorname{Trp}$ & - & - & - & - & - & - & 2 & - & - \\
\hline NEAA $\ddagger$ & - & 124 & - & $115 \cdot 5$ & $100 \cdot 9$ & 88.5 & $86-5$ & - & - \\
\hline EAA§ & - & - & - & - & - & - & - & 124 & - \\
\hline Fishmeal & - & - & - & - & - & - & - & - & 184 \\
\hline Starch, maize & 225 & 171 & 171 & 171 & 171 & 171 & 171 & 171 & 121 \\
\hline Fish oil & 160 & 90 & 90 & 90 & 90 & 90 & 90 & 90 & 80 \\
\hline \multicolumn{10}{|l|}{ Digestible protein } \\
\hline$(g / k g) \|$ & 251 & 372 & 372 & 372 & 372 & 372 & 372 & 372 & 372 \\
\hline Digestible fat $(\mathrm{g} / \mathrm{kg})$ & 181 & 111 & 111 & 111 & 111 & 111 & 111 & 111 & 119 \\
\hline \multicolumn{10}{|l|}{ Digestible energy } \\
\hline$(\mathrm{MJ} / \mathrm{kg})$ & 16 & 16 & 16 & 16 & 16 & 16 & 16 & 16 & 16 \\
\hline
\end{tabular}

* All crystalline amino acids were coated with gelatinized starch.

$\dagger$ Supplied ( $\mathrm{g} / \mathrm{kg}$ basal mix): fishmeal 150 , maize-gluten meal 120 , soya-bean meal 60 , wheat middlings 100 , dried whey 100 , gelatin 30 and vitamin-mineral premixes.

$\ddagger$ NEAA supplied $(\mathrm{g} / \mathrm{kg})$ : Ala $15 \cdot 9$, Asp 25 , Glu 50.6, Gly 11.3, Pro 9.7, Ser $11 \cdot 5$.

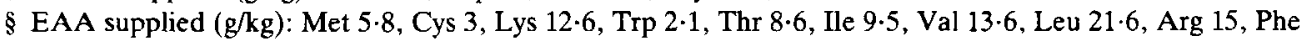
$10 \cdot 2$, Ala 22 .

$\|$ Digestible $\mathrm{N} \times 6.25$.

The contrasting findings of Kim et al. (1991) and ourselves are not easy to explain. Growth rates in the experiments from the two laboratories appear somewhat similar. It has been held that, in warm-blooded animals, there is a constant relationship between essential amino acid requirement and protein intake up to the level of protein required for maximum growth (Almquist, 1972). For this reason amino acid requirements of fish are usually expressed as a proportion of dietary protein as well as on a dry matter basis. If this relationship does indeed hold true for fish also, then an increase in dietary protein 
Table 3. Expt 1. Live-weight gain and feed efficiency of rainbow trout (Oncorhynchus mykiss) fed on either a basal diet or a basal diet supplemented with amino acids for 12 weeks

(Mean initial body wt was $7 \mathrm{~g} / \mathrm{fish}$; each 60 litre fibreglass tank contained sixty fish; there were three replicate tanks per diet. Water temperature was $15^{\circ}$ )

\begin{tabular}{|c|c|c|c|c|}
\hline Diet & $\begin{array}{l}\text { Digestible protein } \\
(\mathrm{g} / \mathrm{kg})\end{array}$ & & $\begin{array}{l}\text { Live-wt gain } \\
\text { (g/fish) }\end{array}$ & $\begin{array}{l}\text { Feed efficiency } \\
\text { (wt gain/feed } \\
\text { intake) }\end{array}$ \\
\hline 1 Basal, high-fat & 251 & & $44.91^{a}$ & $0.79^{a}$ \\
\hline 2 Alanine & 349 & & $45 \cdot 57^{a}$ & $0.87^{\mathrm{b}}$ \\
\hline 3 Gly + Gln & 349 & & $44 \cdot 96^{\mathrm{a}}$ & $0.81^{\mathrm{a}}$ \\
\hline 4 NEAA & 349 & & $44 \cdot 35^{\mathrm{a}}$ & $0.83^{\mathrm{ab}}$ \\
\hline 5 EAA & 349 & & $51 \cdot 69^{\mathrm{b}}$ & $0.95^{\mathrm{c}}$ \\
\hline 6 Fishmeal & 341 & & $53 \cdot 17^{b}$ & $0.96^{\mathrm{c}}$ \\
\hline \multirow[t]{3}{*}{7 High nutrient density } & 402 & & $65.89^{\mathrm{c}}$ & $1 \cdot 18^{\mathrm{d}}$ \\
\hline & & $\operatorname{SEM}(12 \mathrm{df})$ & $0 \cdot 60$ & $0 \cdot 01$ \\
\hline & & HSD & 2.97 & 0.04 \\
\hline
\end{tabular}

HSD, Tukey's honestly significant difference $(P \leq 0.05)$.

a,b.c.d Within the same column values with unlike superscript letters were significantly different.

Table 4. Expt 2. Live-weight gain and feed efficiency of rainbow trout (Oncorhynchus mykiss) fed on either a basal diet or a basal diet supplemented with amino acids for 12 weeks

(Mean initial body wt was $5 \cdot 8 \mathrm{~g} / \mathrm{fish}$; each 60 litre fibreglass tank contained eighty-three fish; there were three replicate tanks per diet. Water temperature was $15^{\circ}$ )

\begin{tabular}{|c|c|c|c|c|}
\hline Diet & $\begin{array}{l}\text { Digestible protein } \\
\qquad(\mathrm{g} / \mathrm{kg})\end{array}$ & & $\begin{array}{l}\text { Live-wt gain } \\
\text { (g/fish) }\end{array}$ & $\begin{array}{c}\text { Feed efficiency } \\
\text { (wt gain/feed } \\
\text { intake) }\end{array}$ \\
\hline 1 Basal, high-fat & 251 & & $34.42^{\mathrm{a}}$ & $0 \cdot 84^{a}$ \\
\hline 2 NEAA & 372 & & $35 \cdot 56^{\mathrm{ab}}$ & $0 \cdot 87^{\mathrm{ab}}$ \\
\hline $3 \mathrm{Ala}+\mathrm{Met}$ & 372 & & $35 \cdot 60^{\mathrm{ab}}$ & $0.88^{\mathrm{ab}}$ \\
\hline $4 \mathrm{NEAA}+\mathrm{Met}$ & 372 & & $35 \cdot 26^{\mathrm{a}}$ & $0 \cdot 88^{\mathrm{ab}}$ \\
\hline $5 \mathrm{NEAA}+\mathrm{Met}+\mathrm{Arg}$ & 372 & & $36 \cdot 68^{\mathrm{ab}}$ & $0.90^{\mathrm{ab}}$ \\
\hline \multicolumn{5}{|l|}{$6 \mathrm{NEAA}+\mathrm{Met}+\mathrm{Arg}$} \\
\hline+ Lys & 372 & & $36 \cdot 74^{\mathrm{ab}}$ & $0.90^{\mathrm{b}}$ \\
\hline \multicolumn{5}{|l|}{$7 \mathrm{NEAA}+\mathrm{Met}+$ Arg } \\
\hline+ Lys $+\operatorname{Trp}$ & 372 & & $37.96^{\mathrm{b}}$ & $0.93^{\mathrm{b}}$ \\
\hline 8 EAA & 372 & & $41.92^{c}$ & $1.03^{\mathrm{c}}$ \\
\hline \multirow[t]{3}{*}{9 High fishmeal } & 372 & & $45 \cdot 44^{\mathrm{d}}$ & $1 \cdot 11^{\mathrm{d}}$ \\
\hline & & $\operatorname{SEM}(16 \mathrm{df})$ & 0.498 & 0.01 \\
\hline & & HSD & $2 \cdot 504$ & 0.06 \\
\hline
\end{tabular}

HSD, Tukey's honestly significant difference $(P \leq 0.05)$.

a,b.c.d Within the same column values with unlike superscript letters were significantly different.

content brought about by adding non-essential amino acids to a diet, would lower essential amino acid level as a proportion of dietary protein.

The addition of non-essential amino acids to a diet containing $251 \mathrm{~g}$ protein $/ \mathrm{kg}$ (Expt 1) was without effect on the activities of certain liver enzymes involved in amino acid 
catabolism. Glutamate dehydrogenase (EC 1.4.1.2), mitochondrial aspartate aminotransferase ( $E C$ 2.6.1.1) and glutaminase $(E C$ 3.5.1.2) activities (expressed as units in the liver of a fish of $100 \mathrm{~g}$ ) did not differ significantly in any of the treatments in Expt 1. Hepatic D-amino acid oxidase ( $E C$ 1.4.3.3) activity was also measured in trout from Expt 1. This enzyme, a flavin-dependent enzyme, serves no obvious metabolic purpose and its activity is not conserved under conditions of riboflavin deficiency (Woodward, 1983). It seemed feasible that, if there are adaptations at the enzyme level to dietary protein restriction, D-amino acid oxidase activity would not be conserved. However, no significant changes in its activity were found.

\section{REFERENCES}

Almquist, H. J. (1972). Proteins and Amino Acids in Animal Nutrition, 5th ed. New York: S. B. Penick.

Barnett, B. J., Cho, C. Y. \& Slinger, S. J. (1982a). Relative bipotency of dietary ergocalciferol and cholecalciferol and the role of and requirement for vitamin $\mathrm{D}$ in rainbow trout (Salmo gairdneri). Journal of Nutrition 112, 2011-2019.

Barnett, B. J., Jones, G., Cho, C. Y. \& Slinger, S. J. (1982b). The biological activity of 25-hydroxycholecalciferol and 1,25-dihydroxycholecalciferol for rainbow trout (Salmo gairdneri). Journal of Nutrition 112, 2020-2026.

Brett, J. R., Shelbourne, J. E. \& Shoop, C. T. (1969). Growth rate and body composition of fingerling sockeye salmon, Oncorhynchus nerka, in relation to temperature and ration size. Journal of the Fisheries Research Board of Canada 26, 2363-2394.

Castell, J. D., Lee, D. J. \& Sinnhuber, R. O. (1972). Essential fatty acids in the diet of rainbow trout (Salmo gairdneri): lipid metabolism and fatty acid composition. Journal of Nutrition 102, 93-100.

Cho, C. Y. (1992). Feeding systems for rainbow trout and other salmonids with reference to current estimates of energy and protein requirements. Aquaculture 100, 107-123.

Cho, C. Y., Kaushik, S. J. \& Woodward, B. (1992). Dietary arginine requirement of young rainbow trout (Oncorhynchus mykiss). Comparative Biochemistry and Physiology 102A, 211-216.

Cowey, C. B. (1988). The nutrition of fish: the developing scene. Nutrition Research Reviews 1, 255-280.

Cowey, C. B., Adron, J. W., Walton, M. J., Murray, J., Youngson, A. \& Knox, D. (1981). Tissue distribution, uptake, and requirement for $\alpha$-tocopherol of rainbow trout (Salmo gairdneri) fed diets with a minimal content of unsaturated fatty acids. Journal of Nutrition 111, 1556-1567.

Cowey, C. B., Adron, J. W. \& Youngson, A. (1983). The vitamin E requirement of rainbow trout (Salmo gairdneri) given diets containing polyunsaturated fatty acids from fish oil. Aquaculture 30, 85-93.

Cowey, C. B., Cho, C. Y., Sivak, J. G., Weerheim, J. A. \& Stuart, D. D. (1992). Methionine intake in rainbow trout (Oncorhynchus mykiss), relationship to cataract formation and the metabolism of methionine. Journal of Nutrition 122, 1154-1163.

Cowey, C. B., Degener, E., Tacon, A. G. J., Youngson, A. \& Bell, J. G. (1984). The effect of vitamin E and oxidized fish oil on the nutrition of rainbow trout (Salmo gairdneri) grown at natural, varying water temperatures. British Journal of Nutrition 51, 443-451.

Fenwick, J. C. (1989). Calcium exchange across fish gills. In Vertebrate Endocrinology: Fundamentals and Biomedical Implications, vol. 3, pp. 319-342 [P. K. T. Pang and M. P. Schriebman, editors]. New York: Academic Press Inc.

Flik, G. \& Perry, S. F. (1989). Cortisol stimulates whole body calcium uptake and the branchial calcium pump in freshwater rainbow trout. Journal of Endocrinology 120, 75-82.

Fontaine, M. M., Delerue, N., Martelly, E., Marchekidon, J. \& Milet, C. (1972). Role des corpuscles de Stannius dans les echanges de calcium d'un poisson teleosteen, l'Anguilla, avec le milieu ambiant (The role of Stannius' corpuscles in the calcium exchange of a teleost fish, the eel, with its surroundings). Comptes Rendus Hebdomadaires Seances Academie Sciences, series D 275, 1523-1528.

Frigg, M. \& Broz, J. (1984). Relationships between vitamin A and vitamin E in the chick. International Journal of Vitamin and Nutrition Research 54, 125-134.

Gutierrez, J., Asgard, T., Fabbri, E. \& Plisetskaya, E. M. (1991). Insulin receptor binding in skeletal muscle of trout. Fish Physiology and Biochemistry 9, 351-360. 
Hilton, J. W., Plisetskaya, E. M. \& Leatherland, J. F. (1987). Does oral 3,5,3'-triiodo-L-thyronine affect dietary glucose utilization and plasma insulin levels in rainbow trout (Salmo gairdneri)? Fish Physiology and Biochemistry 4, 113-120.

Hung, S. S. O., Fynn-Aikins, F. K., Lutes, P. B. \& Xu, R. (1989). Ability of juvenile white sturgeon (Acipenser transmontanus) to utilize different carbohydrate sources. Journal of Nutrition 110, 727-733.

Kim, K.-I., Kayes, T. B. \& Amundson, C. H. (1991). Purified diet development and re-evaluation of the dietary protein requirement of fingerling rainbow trout (Oncorhynchus mykiss). Aquaculture 96, 57-67.

Kim, K.-I., Kayes, T. B. \& Amundson, C. H. (1992a). Requirements for sulfur amino acids and utilization of D-methionine by rainbow trout (Oncorhynchus mykiss). Aquaculture 101, 95-103.

Kim, K.-I., Kayes, T. B. \& Amundson, C. H. (1992b). Requirements for lysine and arginine by rainbow trout (Oncorhynchus mykiss). Aquaculture 106, 333-344.

Mazur, G. N., Higgs, D. A., Plisetskaya, E. \& March, B. E. (1992). Utilization of dietary starch and glucose tolerance in juvenile chinook salmon (Oncorhynchus tshawytscha) of different strains in seawater. Fish Physiology and Biochemistry 10, 303-313.

National Research Council (1981). Nutrient Requirements of Domestic Animals, no. 16. Nutrition Requirements of Coldwater Fishes. Washington, DC: National Research Council.

National Research Council (1984). Nutrient Requirements of Domestic Animals. Nutrient Requirements of Poultry. 8th revised ed. Washington, DC: National Research Council.

National Research Council (1988). Nutrient Requirements of Domestic Animals. Nutrient Requirements of Swine. 9 th revised ed. Washington, DC: National Research Council.

Sakamoto, S. \& Yone, Y. (1979). Mineral mixture in purified diet for red sea bream. Nippon Suisan Gakkaishi 45, 873-877.

Sheridan, M. A., Plisetskaya, E. M., Bern, H. A. \& Gorbman, A. (1987). Effects of somatostatin-25 and urotensin II on lipid and carbohydrate metabolism of coho salmon, Oncorhynchus kisutch. General and Comparative Endocrinology 66, 365-372.

Tocher, D. R. (1990). Incorporation and metabolism of $(n-3)$ and $(n-6)$ polyunsaturated fatty acids in phospholipid classes in cultured rainbow trout (Salmo gairdneri) cells. Fish Physiology and Biochemistry 8 , 239-249.

Tocher, D. R. \& Mackinlay, E. M. (1990). Incorporation and metabolism of $(n-3)$ and ( $n-6)$ polyunsaturated fatty acids in phospholipid classes in cultured turbot (Scophthalmus maximus) cells. Fish Biochemistry and Physiology 8, 251-260.

Voss, A., Reinhart, M., Sankarappa, S. \& Sprecher, H. (1991). The metabolism of 7,10,13,16,19-docosapentaenoic acid to $4,7,10,13,16,19$-docosahexaenoic acid in rat liver is independent of a 4-desaturase. Journal of Biological Chemistry 266, 19995-20000.

Wilson, R. P. (1991). Handbook of Nutrient Requirements of Fish. Boca Raton, Florida: CRC Press, Inc.

Wilson, R. P. \& Poe, W. E. (1987). Apparent inability of channel catfish to utilize dietary mono- and di-saccharides as energy sources. Journal of Nutrition 117, 280-285.

Woodward, B. (1983). Sensitivity of hepatic D-amino acid oxidase and glutathione reductase to the riboflavin status of the rainbow trout (Salmo gairdneri). Aquaculture 34, 193-201.

Woodward, B. (1989). Dietary requirements of some water soluble vitamins for young rainbow trout. Proceedings of the Twenty-fifth Annual Nutrition Conference for Feed Manufacturers, pp. 187-195. Ottawa, Canada: Canadian Feed Industry Association. 